\title{
Assessment of the performance of non-ryegrass pasture mixtures
}

\author{
D. J. MUSGRAVE and M. J. DALY \\ Aoraki Organic Farms Ltd, 21 R.D., Geraldine \\ waihib@ihug.co.nz
}

\begin{abstract}
Drawing on practical farming experience and on-farm observations, plus a range of trials from both published and unpublished sources, the authors have compared the relative benefits of mixed species pastures (MSP), also known as mixed herb leys, with traditional ryegrass white clover pastures. This collection of data, demonstrates production advantages using MSP, with lower weed and pest problems, leading to economic benefits and therefore contributing to more sustainable pastoral systems.
\end{abstract}

Keywords: animal production, endophyte, Festuca arundinacea, financial return, grassgrub, internal parasites, Lolium perenne, thistles

\section{Introduction}

Ryegrass and white clover based pastures are used very widely on New Zealand farms for their quick establishment, cheap seed, and ease of management and reasonable productivity. There seems to be a lack of awareness that ryegrass and to a lesser extent white clover, as species, have a number of shortcomings that affect the whole farming system. These shortcomings include poor tolerance of drought and grassgrub attack, weed invasion (i.e. thistles) and problems related to endophyte, yet such shortcomings are not shared by some alternative species.

In this paper we review the attributes of other species that can be used in pasture mixes to create more productive and persistent pastures, present some grazing trial data and examine the economics of sowing different pastures.

\section{Pasture productivity}

In recent years there have been an increasing number of reports demonstrating the increased productivity that can be achieved by the use of non-ryegrass pastures or multi-species pastures (MSP) e.g. Judd et al. (1990), Ruz-Jerez et al. (1991), Johnson et al. (1994), Daly et al. (1996), Rollo et al. (1998). Generally these comparisons have shown increased spring and summer production compared to ryegrass, little difference over autumn and in some situations increased winter growth.

\section{Animal productivity}

Just including Pawera red clover in the pasture mix gave an increase in beef meat output of about $10 \%$ in a grazing trial in the Manawatu (Cosgrove \& Brougham 1988), an increase in milk production of $24 \%$ on a Bay of Plenty farm (Keogh \& Thomson 1996) and a $24 \%$ increase in weaned lamb growth rate in the Manawatu (Keogh \& Thomson 1996). These results are particularly significant in organic systems reliant on clovers to build soil nitrogen levels, as there is a strong relationship between nitrogen fixation and productivity of clovers (Sinclair 1973)

A grazing comparison of tall fescue and ryegrass pastures in Hawkes Bay (Wright et al. 1985) showed that for lambs fed the same pasture allowance in early summer, carcass weight gains were not different between the pasture types and taking a previous silage cut made a significant impact on ryegrass liveweight gain, but had little effect on lamb liveweight gain on tall fescue pastures. However for ewes grazed on the same pastures from January to March the higher live weight at mating on the tall fescue based pastures, which resulted from better autumn growth rates (about $100 \mathrm{~g} / \mathrm{hd} /$ day difference during the trial period) gave an extra $11 \%$ and $20 \%$ lambs born/ewes mated on the tall fescue pastures in the two years of the trial.

Similar results have come from comparisons with more complex mixtures with deer in Otago (Table 1).

Other studies have looked at the advantages from MSP on milk production, where on-farm studies in the Waikato have shown increases of around 16-23\% (Thom et al. 1998, 2002). Several of these reports attribute much of the increased production to the higher legume content of the pastures which do not contain high endophyte ryegrass, although freedom from ryegrass staggers and facial eczema are also mentioned (Thom et al. 1997).

\section{Animal health \\ Endophyte}

The effects of the alkaloids produced by the various ryegrass endophyte fungi that protect ryegrass from damage by Argentine stem weevil have been extensively documented (e.g. Woodfield \& Matthew 1999).

Fletcher et al. (1999), reported a list of known health and production problems in sheep associated with grazing perennial ryegrass with endophyte. These included reduced weight gains, increased dags and flystrike, heat stress and staggers.

It is very difficult to get young sheep to grow any faster than 120-150 g/day during their first autumn no 
matter how lush the high endophyte ryegrass pasture, whereas on species such as timothy, tall fescue, Prairie grass or low endophyte ryegrass and lucerne, growth rates of 200-240 g/day are possible (Scales et al. 1995; Fraser \& Rowarth 1996), and on chicory, growth rates in excess of $300 \mathrm{~g} /$ day are possible (Scales et al. 1995)

This suggests that young stock grazing high endophyte ryegrass are under considerable dietary stress. Such stress is likely to make them more susceptible to internal parasites. The authors' on-farm experience have been that the need for synthetic anthelmintics is substantially less when young stock are grazed on mixed pastures free from high endophyte ryegrass.

Livestock such as deer and Alpacas are extremely susceptible to ryegrass staggers, so it is more important to have endophyte free pastures available for such animals. Alpacas are so susceptible to ryegrass staggers that once exposed to endophyte poisoning, the staggers will reoccur whenever the animals are stressed (Anne Rogers pers. comm.).

\section{Mineral levels}

Having a range of species in a pasture is an accepted way to balance the mineral status of the diet i.e. tall fescue tends to have low sodium content, which can be a problem in simple mixtures, but is not in complex mixtures. Including herbs, such as chicory or plantain in the pasture, is a particularly effective way of increasing the mineral content of the pasture (Crush \& Evans 1990; Stewart 1996) which can give a useful improvement in animal performance (Scales et al. 1995).

Scales et al. (1995) and Knight et al. (1996) have shown that lambs feeding on lucerne and chicory can have lower levels of internal parasites, which may have the potential to reduce the need for anthelmintics.

Thus it is important for optimum livestock health and performance that mixed pastures are used - it is not sufficient to plant novel endophyte ryegrass based pastures.

\section{Weed infestation}

Ryegrass pastures are quite prone to invasion by weeds such as thistles, particularly after a dry autumn or grassgrub/Porina damage. A grazing trial at Geraldine was established in 1987 to investigate compatibility of grasses and legumes with Puna chicory. The trial was laid out with three replicates with $10 \mathrm{~m}^{2}$ plots and dense, even swards were formed across the whole trial. The trial was separately fenced and periodically grazed with large numbers of sheep during the first three years, after which the fence was removed and grazed as a typical rotationally grazed sheep pasture. In the second year, following a very dry autumn, counts of nodding thistle were made and after progressive invasion by Californian thistle, further counts were taken in Year 7.

Thistle numbers recorded illustrate the potential for other pasture species to reduce weed invasion compared to ryegrass (Table 2). The general pattern was that those species that best form a complete sward, with good cover of the sown species, such as tall fescue and cocksfoot, were best at preventing the invasion of both Nodding and Californian thistles.

A further noteworthy observation was that the numbers of chicory plants were very low by the time the Californian thistle counts were taken in Year 7. Yet wherever chicory had been included in the original mixture, the number of Californian thistle plants was very low. There were clear, straight lines across the trial, dense Californian thistle on one side and nothing on the other side where the chicory had been grown. Since most Californian thistle rhizome growth commonly occurs in the compacted zone just below the cultivation zone, it seems likely that the deep taproot of chicory may be breaking up compacted layers down the soil profile, and making conditions unfavourable for Californian thistle growth.

\section{Insect damage}

The numbers of grassgrub larvae in the soil are controlled into a cyclical pattern by natural pathogens and predators. Unfortunately the level at which grassgrub numbers usually start to crash is higher than the level at which substantial damage starts to happen to ryegrass-based pastures. Two trials that measured the effects of a high population of grassgrub larvae on grass pasture productivity, showed that of all the commonly used grasses, ryegrass was by far the most sensitive (Tables 3 and 4)

A more recent study with phalaris mixtures (Fraser 1994) confirmed that pasture and animal productivity of species such as tall fescue, phalaris and cocksfoot are little affected by grass grub while ryegrass productivity is substantially reduced. An observation by David Musgrave (Author), on his own farm at Woodbury near Geraldine, is that, since using MSP for 15 years, the visual appearance of grassgrub has been negligible. However on sampling the soil on one occasion, he found that the population of grubs was $600 / \mathrm{m}^{2}$ - an unusually high population, which would have eliminated a ryegrass based pasture, but in this case still supported a productive MSP.

\section{Business case Assumptions}

The financial data are taken from Profit Plan Gross Margins provided by an Ashburton based farm management consultant (Rae 2003). The returns, as presented assume a conservative $10 \%$ increase in animal 
Table 1 Spring/summer productivity of deer grazing various pasture types at Invermay.

\begin{tabular}{lccrr}
\hline Pasture types & $\begin{array}{c}\text { Grazing days } \\
\text { (stag equivalents) } \\
\text { (over spr/sum) }\end{array}$ & $\begin{array}{c}\text { Deer live- } \\
\text { weight gain } \\
\text { (kg/ha/day) }\end{array}$ & $\begin{array}{c}\text { Total spr/sum } \\
\text { liveweight gain * } \\
\text { (kg/ha) }\end{array}$ & $\begin{array}{c}\text { Relative } \\
\text { productivity * }\end{array}$ \\
\hline High endophyte Nui ryegrass & 1089 & 6.05 & 11.4 & 100 \\
Low endophyte Nui ryegrass & 1769 & 5.52 & 9.9 & 86 \\
Roa tall fescue & 2326 & 6.40 & 14.9 & 130 \\
Roa tall fescue/Pawera red & 2470 & 7.17 & 17.7 & 155 \\
clover and Puna chicory & 460 & & \\
LSD & 4 & & \\
\hline After Stevens et. al. 1992 (total liveweight gain calculated from the data).
\end{tabular}

Table 2 Levels of thistle infestation of various pasture species.

\begin{tabular}{llcc}
\hline Sown species & Cultivar & $\begin{array}{c}\text { Nodding thistle } \\
\left.\text { (plants } / \mathrm{m}^{2}\right) \\
\text { Year 2 }\end{array}$ & $\begin{array}{c}\text { Californian thistle } \\
\left(\mathrm{stems} / \mathrm{m}^{2}\right) \\
\text { Year 7 }\end{array}$ \\
\hline Perennial ryegrass & Droughtmaster & 1 & 30 \\
Chicory & Puna & 0.1 & 2 \\
Tall fescue & Au Triumph & 0.2 & 1 \\
Tall fescue & Roa & 0.8 & 6 \\
Cocksfoot & Saborto & 0.1 & 4 \\
Prairie grass & Matua & 1.7 & 33 \\
Sheep's burnet & & 0.9 & 31 \\
Italian ryegrass & Concord & 3 & 27 \\
\hline
\end{tabular}

Table 3 Autumn and winter pasture production in the presence or absence of grassgrub at Wairakei.

\begin{tabular}{llccc}
\hline & Cultivar & $\begin{array}{c}\text { Insecticide treated } \\
(\mathrm{kg} / \mathrm{ha})\end{array}$ & $\begin{array}{c}\text { Untreated } \\
(\mathrm{kg} / \mathrm{ha})\end{array}$ & $\%$ loss \\
\hline Perennial ryegrass & Ruanui & 2480 & 520 & 79 \\
Tall fescue & S170 & 3180 & 2870 & 10 \\
Cocksfoot & Apanui & 2130 & 1760 & 17 \\
Prairie grass & Matua & 2520 & 2040 & 19 \\
White clover & Huia & 1700 & 500 & 71 \\
\hline Adapted from East etal. (1980). & & & \\
\hline
\end{tabular}

performance from mixed pastures (a difference exceeded in all the trials referred to in Animal performance), that only one topping in the second season is required to control thistle growth (our experience) and that mixed pastures do not need topping to remove seed head growth to maintain pasture quality as most ryegrass pastures do (our experience).

We have made an attempt to quantify the potential costs and returns from planting a mixed species pasture compared to a simple ryegrass-white clover pasture (Table 7). The costs and returns are based on an East Coast sheep/beef farm and Taranaki dairy farm, but it is a relatively simple exercise to apply a similar cost/ benefit analysis to an individual farm situation.

Net returns from $16-25 \%$ higher by using MSP
Table 4 Grassgrub numbers and autumn pasture production in the presence or absence of grassgrub in Central Hawkes Bay (averaged over 3 years).

\begin{tabular}{lcc}
\hline & $\begin{array}{c}\text { Autumn } \\
\text { grass grub } \\
\text { numbers } \\
\left(\mathrm{no.} / \mathrm{m}^{2}\right)\end{array}$ & $\begin{array}{c}\text { Autumn } \\
\text { dry matter } \\
\text { production } \\
\text { (\% loss) }\end{array}$ \\
\hline Ryegrass & 180 & 33 \\
Tall fescue & 235 & 6 \\
Phalaris & 247 & 18 \\
Prairie grass & 206 & 14 \\
Cocksfoot & 106 & 10 \\
Browntop & 181 & 37 \\
\hline
\end{tabular}

After Kain et. al. (1979) 
Table 5 Costs and returns from various pasture types.

\begin{tabular}{|c|c|c|c|}
\hline & $\begin{array}{c}\text { Ryegrass(with } \\
\text { AR1)/white clover }\end{array}$ & $\begin{array}{l}\text { Clover-based mixed } \\
\text { pasture (MSP) }\end{array}$ & $\begin{array}{l}\text { Lucerne-based mixed } \\
\text { pasture (MSP) }\end{array}$ \\
\hline \multicolumn{4}{|l|}{$\begin{array}{l}\text { Sheep \& beef } \\
\text { (over 3yrs) }\end{array}$} \\
\hline Income(10 su /ha) & $\$ 660 \times 3=\$ 1980$ & $\$ 726(660+10 \%)=\$ 2178$ & $\$ 726(660+10 \%)=\$ 2178$ \\
\hline Seed costs & $\$ 240(\$ 210-280)$ & $\$ 250(\$ 240-265)$ & $\$ 230(\$ 220-250)$ \\
\hline \multicolumn{4}{|l|}{ Variable costs - } \\
\hline Thistle control & $\$ 60$ (3l Tropotox) & $\$ 20$ (1 topping) & $\$ 20$ (1 topping) \\
\hline Pasture topping & $\$ 60$ (1 per annum) & Nil & Nil \\
\hline Grassgrub control & $\$ 75$ (BioSheild) & Nil & Nil \\
\hline Total costs & $\$ 435$ & $\$ 270$ & $\$ 250$ \\
\hline Net return & $\$ 1,545$ & $\$ 1908$ (23\% increase) & $\$ 1928$ (24.8\% increase) \\
\hline \multicolumn{4}{|l|}{ Dairy (over 3yrs) } \\
\hline Income (12 su /ha) & $\$ 610 \times 3=\$ 1830$ & $\$ 671(610+10 \%)=\$ 2013$ & \\
\hline Seed costs & $\$ 185(\$ 175-230)$ & $\$ 310(\$ 240-360)$ & \\
\hline \multicolumn{4}{|l|}{ Variable costs - } \\
\hline Thistle control & $\$ 60$ (3l Tropotox) & $\$ 20$ (1 topping) & \\
\hline Pasture topping & $\$ 60$ (1 per annum) & Nil & \\
\hline Grassgrub control & $\$ 75$ (BioSheild) & Nil & \\
\hline Total costs & $\$ 380$ & $\$ 330$ & \\
\hline Net return & $\$ 1,450$ & $\$ 1,683$ (16\% increase) & \\
\hline
\end{tabular}

compared to ryegrass based pasture over a 3 year period are demonstrated (Table 5). It is widely assumed that the cost of sowing mixed species pastures is substantially greater than for a simple ryegrass-white clover pasture. The cost of using ryegrass seed containing the new novel endophytes means that this is currently not the case. Since the novel endophytes only partially address the limitations of ryegrass as a pasture species, this relatively simplistic look at the economic performance of various pasture mixtures highlights the need for farmers to reevaluate their choice of pasture mix.

\section{Conclusions}

The authors have used mixed species pastures extensively on farms on the summer dry East Coast areas, with useful increases in productivity and profitability. Similar reports have been published from many areas of New Zealand. By addressing many of the inherent limitations of ryegrass-based pastures, non-ryegrass mixed species pastures are able to have a considerable impact on the health and productivity of a wide diversity farming systems throughout the country, thus contributing to the overall sustainability of these pastoral systems.

\section{REFERENCES}

Cosgrove, G.P.; Brougham, R.W. 1988. Pasture strategies for dairy beef production. Proceedings of the New Zealand Grassland Association 49: 57-62.

Crush, J.R.; Evans, J.P.M. 1990. Shoot growth and herbage element concentrations of Grasslands Puna chicory under varying soil $\mathrm{pH}$. Proceedings of the
New Zealand Grassland Association 51: 163-166. Daly, M.J.; Hunter, R.M.; Green, G.N.; Hunt, L. 1996. A comparison of multi-species pasture with ryegrasswhite clover pasture under dryland conditions. Proceedings of the New Zealand Grassland Association 58: 53-58.

East, R.; Kain, W.M.; Douglas, J.A. 1980. The effect of grassgrub on the herbage production of different pasture species in the Pumice Country. Proceedings of the New Zealand Grassland Association 41: 105-115. Fletcher, L.R.; Sutherland, B.L.; Fletcher, C.G. 1999. The impact of endophyte on the health and productivity of sheep grazing rye-grass based pastures. Ryegrass Endophyte: An essential New Zealand Symbiosis. Grassland Research and Practice Series 7. 11-17.

Fraser, T.J. 1994. Persistence of dryland pasture species in mixed swards in Canterbury. Proceedings of the New Zealand Grassland Association 56: 77-79.

Fraser, T.J.; Rowarth, J.S. 1996. Legumes, herbs or grass for lamb performance? Proceedings of the New Zealand Grassland Association 58: 49-52.

Johnson, R.J.; Thomson, N.A.; McCallum, D.A.; Judd, T.G. 1994. An evaluation of tall fescue, phalaris and cocksfoot in mixes as an alternative to single-species pastures. Proceedings of the New Zealand Grassland Association 56: 133-138.

Judd, T.G.; Thomson, N.A; McCallum, D.A. 1990. Pasture management and pasture species for improved dry matter production in south Taranaki. Proceedings of the New Zealand Grassland 
Association 51: 109-112.

Kain, W.M.; Slay, M.; Atkinson, D.S. 1979. Evaluation of grassgrub-plant interactions of grasses sown with and without white clover in Hawkes Bay. Proceedings of the New Zealand Weed and Pest Control Society 32: 89-91.

Keogh, R.G.; Thomson, D. 1996. Red clover: milk production and growth rate responses. Proceedings of the New Zealand Grassland Association 58: 271.

Knight, T.L.; Moss, R.A.; Fraser, T.J.; Rowarth, J.S.; Burton, R.N. 1996 Effect of pasture species on internal parasites of lambs. Proceedings of the New Zealand Grassland Association 58: 59-62.

Rae, G. 2003. Profit Plan - Crop and livestock gross margins. Canterbury Agriculture Ltd, Ashburton.

Rollo, M.D.; Sheath, G.W; Slay, M.W.A.; Knight, T.L.; Judd, T.G.; Thomson, N.A. 1998. Tall fescue and chicory for increased summer forage production. Proceedings of the New Zealand Grassland Association 60: 249-253.

Ruz-Jerez, B.E.; Ball, P.R.; White, R.E.; Gregg, P.E.H. 1991. Comparison of a herbal ley with a ryegrasswhite clover pasture and pure ryegrass sward receiving fertiliser nitrogen. Proceedings of the New Zealand Grassland Association 53: 225-230.

Scales, G.H.; Knight, T.L.; Saville, D.J. 1995. Effect of herbage species and feeding level on internal parasites and production performance of grazing lambs. New Zealand Journal of Agricultural Research 38: 237 -
247.

Sinclair, A.G. 1973. Non-destructive acetylene reduction assay of nitrogen fixation applied to white clover plants growing in soil. New Zealand Journal of Agricultural Research 16: 263-270.

Stevens, D.R.; Drew, K.; Laas, F.; Turner, J.D. 1992. Deer production from ryegrass- and tall fescue-based pastures. Proceedings of the New Zealand Grassland Association 54: 23-26.

Stewart, A.V. 1996. Plantain - a potential pasture species. Proceedings of the New Zealand Grassland Association 58: 77-85.

Thom, E.R.; Clark, D.A.; van Vught, V.T.; Waugh, C.D.; 1998. Pasture species and drought impact on milk yield 1. Milk yield responses in the Waikato. Proceedings of the New Zealand Grassland Association 60: 39-44.

Thom, E.R.; Burggraaf, V.T.; Waugh, C.D.; Clark, D.A. 2002. Effects of pasture species and irrigation on milk production over four summers in the Waikato. Proceedings of the New Zealand Grassland Association 64: 215-220.

Woodfield, D.R.; Matthew, C. 1999. Eds. Ryegrass Endophyte: An essential New Zealand Symbiosis. Grassland Research and Practice Series 7.168 pp.

Wright, D.F.; Slay, M.W.A.; Hamilton, G.J.; Patterson, D.J. 1985. Tall fescue for finishing lambs and flushing ewes in Hawkes Bay. Proceedings of the New Zealand Grassland Association 46: 173-177. 
